\title{
The impact of technological advancement on total factor productivity of cotton: a comparative analysis between Pakistan and India
}

\author{
Malik Shahzad Shabbir ${ }^{1 *}$ and Nusrat Yaqoob²
}

*Correspondence:

Mshahzad786.pk11@gmail.com

${ }^{1}$ University of Lahore, Lahore, Pakistan

Full list of author information is available at the end of the article

\begin{abstract}
Pakistan and India are the two major producers of the cotton, the most demanding crop of the world which is known as white gold. However, for some recent years, it deems that Pakistan's share in the international textile market dwindles compared to India. Thereby, the study will investigate whether the productivity of the crop per hectare is the reason or area of the crop, in the countries which lead to a higher share of India in the international market. In addition, which country has a comparative advantage in terms of cotton yield $\mathrm{kg}$ per hectare, particularly due to technological advancement in India and Pakistan's agriculture sector? And this study also examines which country has exploited natural and technological inputs most. The time-series data from 1954 to 2017 have been used in this study, the results of the study are drawn using two-stage analysis. At first, we get total factor productivity (TFPCC) for both the countries using Tornqvist-Theil Index: total factor productivity input-output method. Then, the obtained variable has been employed as a regress and variable on farm and non-farm regressors. The ARDL: autoregressive distribution lag regression model has been applied on [area of cotton, fertilizer consumption $\mathrm{kg} / \mathrm{ha}$, high yield varieties (HYV) seeds, electricity consumption in agriculture sector, agriculture labor force, and irrigation by canal water and tube well water, besides tractors] to find the technological advancement impact on the TFPC of cotton. The results explore that overall improvement in farm inputs has a more stable impact on the productivity of cotton in Pakistan, whereas HYV seeds, mechanization, and area are the real reason for the growth in India.

Keywords: Cotton, Technological advancement, Total factor productivity, Pakistan and India
\end{abstract}

\section{Introduction}

Cotton is a major fiber cash crop of Pakistan and India after food crops, wheat, and sugarcane. Moreover, cotton is the crop which produces many byproducts, such as, lint, edible oil, and cloths; these finished items of the crop have 10 percent shares in the GDP of Pakistan. The most notable point is that in the international market, India is trailing to the United States of America, whereas Pakistan instead to export, importing the cotton due to decrease in its area under the crop (World textile information report 2017, USDA 
annual gain report 2017). There is no denying the fact that Pakistan and India are the two major producers of cotton in South Asia. However, for the last many years, Pakistan has been facing daunting challenges like the cropped area of cotton has substantially minimized in the country. Despite having similar topography, physiography, and even having lower yield kg per hectare in India, the country has become an eminent player of the raw cotton, yarn, lint, and in, textile (readymade apparel industry) in the world. India is the second biggest country in the world which owns a huge tract of fertile agriculture land, so, the country has a comparative advantage in terms of cotton area under cultivation. The crop occupies (7.86) million ha area of Pakistan, and (9.88) million hectares area of India is under the cultivation of cotton.

Pakistan and India both of the countries have tropical and sub-tropical areas where cotton is being grown; also, the soil structure is the same in two of the countries. Apart from this, the yield of cotton in sub-continent: Pakistan and India are 1.5-2 percent lower than to rest of the world, even irrigated area of the countries is lagging behind in terms of lint per hectare from the rain-fed cotton growing areas of the world. However, despite these shortcomings, India has espoused as the leading producer and consumer of the crop since 2011-2012, because 27 percent of the world cotton supply comes from India (economic survey of Pakistan 2016-2017). It is true that the area under cotton is declining in Pakistan since 2004-2005; unfortunately, this situation has been aggravating since 2013-2014, and by the ongoing year, 14.2 percent sowing area of the crop has decreased. Before 2014-2015, it was 2.902 million hectares, which is currently 2.489 million ha where cotton is been cultivated in Pakistan. The prime causes of decline in crop yield $\mathrm{kg}$ per hectare and decline in area are pest infestation, unskilled farming practices, and introduction of less of environment friendly and uncertified (GMO) seed for local cultivation, agriculture statistics of Pakistan (2011), economic survey of Pakistan (20172018). India is facing similar challenges; besides this, at present, India yield kg per hectare is $504 \mathrm{~kg} / \mathrm{ha}$, whereas Pakistan yield $\mathrm{kg}$ is $730 \mathrm{~kg} / \mathrm{ha}$ and the country has produced 10,671 million bales. Contrast to Pakistan, India has produced 28.5 million bales, which is up to 5.6 percent more than previous years by 12.3 million, besides the area under cultivation of cotton. In India, area of the crop has 13 percent expanded during (20172018) year compared to the previous year (2016-2017).

Since 2015, India has been the world largest producer of cotton, world's second consumer 7th importer, third biggest exporter, and third country of the world, which has ending stalk. Contrast to India, Pakistan is the world 5th producer, third biggest consumer, sixth importer, whereas Pakistan has not been exporting raw cotton since 2010, Pakistan is the fourth country which ends up ending stalk (USDA cotton outlook 2019). Although India has a comparative advantage in terms of area, but the Indian population has reached to its steady state, and hence, its demand for apparel has increased to manifold. Therefore, the situation demands that if the only area is the reason for higher production in India, then what measures Pakistan can take to compete with its neighboring competitor to maintain its equilibrium in the international market. For this reason, technological advancement, adoption of the innovative technique, and speed of learning skill are critical to know. Therefore, the study is being conducted, because no prior comparative analysis is available which did ever measure the technological advancement impact on the countries in terms of comparative analysis of productivity of cotton. Besides that, 
it is imperative to know which country's farmers are more progressive in terms of technology adoption and to learn knowledge-based skills. As in long terms, it will enable Pakistan to counter with the supply and demand gap effectively.

Since the advent of Meiji revolution (1878), it had widely been assumed that high yield variety genetically modified seeds increase the crop productivity substantially, Fatima et al. (2016), as it did in Japan and later on in Korea and Taiwan. The study will investigate the following question's answer: What are the major reasons, due to which area of the crop is shrinking in Pakistan? Whether Indian cotton growers are more progressive or Pakistan's growers?

The subsequent section of the study is organized in this way that (Sect. 2) deals with methodology and a detailed description of the variables. Finally in Sect. 3, we discussed results of ADF and ARDL: autoregressive distributed lagged model, and in the end, we conclude the study results besides suggested policies and framework to mitigate the problem of recent phenomena of lower growth of cotton.

\section{Literature review}

These HYV seeds were supplemented by irrigation facilities and mechanization, during green revolution consequently, productivity accelerated vigorously in late in 1960s. At very first, Wizarat (1981) calculates total factor productivity of Pakistan agriculture sector by employing arithmetic input-output index approach. The objective of the study is to find the sources of agriculture growth in Pakistan. The data comprise over the period from 1953 to 1978, pre- and post-green revolution. Results of the study disclose that live stalk and private tub wells accelerated the growth of the sector during the year 19591960, but the real revolution in the sector came after 1967-1968 when high yield variety seeds were introduced by the government. In nutshell, Wizarat's (1981) study provides the base for further research on the topic of technological advancement impact on the agriculture sector. After her, Eisner (1985) said that it is the variation in life and lasting of inputs which are used in the production function. In economics, it is recognized that investment should include improvement in the land, development of human, and social capital that is called human capital formation. Human capital is the stalk of knowledge, expertise, and management characteristics, (Coen and Eisner 1987). Moreover, total factor productivity is the measure, which estimates and takes into account all the factor and inputs, because it is free and independent of partial factor productivities shortcomings. Rosegrant and Evenson (1993) identified that modern farm inputs to increase the productivity of the crop. The study measures the total productivity of the South Asian region using the data from 1960 to 1985 . The study is a comparative analysis of partial factor productivities, for rice, and wheat between Pakistan India and Bangladesh. Results of study discloses that yield kg per hectare in Pakistan in terms of wheat has increased substantially, since the introduction of high yield variety seeds. It is true that resources are scarce so as innovation provides ease to farmers they tended to invest more, the notable point is that research and government expenditure on to the extension of the infrastructure of rural areas, and education integrates the growth more rapidly. Dean et al. (1998), and Fernald and Ramnath (2004) raised the importance of many other inputs, and they called total factor productivity a multifactor method to estimate the productivity and growth of the agriculture sector. Khan (1997) estimated Pakistan's agriculture TFPc 
for the overall agriculture sector and uses data set from 1960 to 1996 . He found that since technology has commenced output has increased substantially. Sabir and Ahmad's (2003) study explores that economic growth in Pakistan's agriculture sector was higher during and soon after the reform period due to thence government being committed. Chang and Zepeda (2001) indicates that although there are three sources of productivity, land-labor, and capital, and the fourth one is "public investment on human capital, because it plays critical role. In her theoretical study, she emphasized that examination of extension in knowledge is a new element to get true results of agriculture productivity, particularly in the least developed countries. The previous study literature review explores that most of the economist used Tornqvist-Theil Index approach and ordinary least square as a method of estimation; besides Tornqvist-Theil Index, some of the economists applied Malmquist Index approach. Moreover, some of the agriculture economist of India like Chaudhary (2012) estimates the total factor productivity of Indian agriculture state wise. For this study, she employs non-parametric sequential Malmquist, ${ }^{1}$ total productivity index using data from 1983 to 2006. In the study, total factor productivity is further decomposed in technical and efficiency changes across the states. Results of the study reveal that there are very few states in India where technical change is the main reason for improvement. However, contrast to technical change, many of the sample states of the country are not much efficient to reap the benefit of technological change, thereby farmers of the states are not producing the optimum level of agriculture output. Rehman et al. (2016) investigate the relationship between agriculture gross domestic product (AGDP) and cotton yield kg per hectare. The study further included fertilizer consumption, the area under the crop over the period from 1970 to 2015 . $\mathrm{He}$ uses $\mathrm{ADF}$, to find stationarity of the variables in the long run, then uses cointegration test, for regression analysis, and finally, he employs ordinary least square, (OLS) method. Results of the study explore that output of cotton, fertilizer consumption, has a positive relationship with the agriculture GDP, whereas area has a negative relationship. In previous studies of agricultural growth and technological advancement impact on the sector, capital and labor had been the major inputs. Literature review for this study explores that total factor productivity is the best measure to capture the effects of technological advancement on a wide range of crops and overall agriculture sector, because total factor productivity (TFPC) is basically a residual of output and input. Therefore, the difference of variation in output due to variation of input application gives insight knowledge about the impact of modern farm inputs usage on crop growth per ha

Since the 1960s, intensive population growth has exacerbated land utilization; thereby, further extension in the cultivated area has become very limited, due to being used of agricultural land for residential purpose. Thereby, because of this problem, yield kg per hectare of the crop and overall agriculture output can only be increased by increasing factor productivity of the sector. It was a new classical economist Solow (1957) and Kendrick (1973) who presented the theory of innovation regarding technological advancement. The theory takes into account a robust increase in population on given natural resources, land, labor, and water especially.

${ }^{1}$ Which she developed by her own as per her sample data requirement. 
Prior to the green revolution, economist used partial factor productivity index to measure productivity of the sector, but it gave misleading results, consequently, Denison (1967), Kendrick (1973), and Christensen (1975) attach the importance to total factor productivity index, and finally, Solow (1957) devised it. The index is a weighted sum of all input and output indices, the input-output included land, labor, capital stalk, chemical fertilizer conventional agricultural inputs, and the index generally includes land, labor, and physical and human capital. Many of the studies have been conducted in Pakistan, India, and other regions of the world in which total factor productivity index has been used to get the true level of productivity of the agriculture sector by employing various approaches like Wizarat (1981), used arithmetic index approach to get TFPc results using data from 1953 to 1979, rose Rosegrant and Evenson (1993), Saleem et al. (2019), Sarel and Robinson (1997) Cornejo and Shumway (1997), Shabbir (2015, 2016), Antle and Capalbo (1988), Jin et al. (2002), Ali and Byerlee (2000), Coelli and Rao (2003), Mukherjee and Kuroda (2003), Ali (2004), and used Tornqvist-Theil Index approach, to get TFPC results. However, Wizarat (1981)'s study has many shortcomings such as non-availability of data, and perfect substitutability between inputs which make her analysis incomplete. Rosegrant and Evenson (1993) investigated the gap between the productivity of India and Pakistan using the data from 1956 to 1985 for rice and wheat productivity in Indian and Pakistan's Punjab. In most of the studies, total factor productivity index computed aggregate agriculture output of all crops including major and minor like wheat, maize, sugarcane, vegetables, and pulses, whereas in inputs, land labor, capital (tractors, tube wells, and animals) besides fertilizers and pesticides quantity with respect to their prices.

There are some country-specific studies about some other problems of cotton such as Shuli et al. (2018) overview cotton and its future prospectus, and Sadashivappa and Qaim (2009) analyzes BT cotton development and role of government in seed price intervention, Ashraf et al. (2018) discuss about the future of cotton and its outlook on the year of 2025 using data from 1990 to 2018. In this study, compound growth rate formula has been used to get the results for forecasting years ahead. Results of the study show an increase in the area of cotton under the cultivation, but in reality, we are observing that instead of increasing area of the crop is decreasing. However, none of the studies is available on to date, whichever estimates total factor productivity of cotton particularly in terms of comparative advantage with respect to technological advancement impact on India and Pakistan.

\section{Materials and methods}

This study draws a great deal of inspiration from Rosegrant and Evenson's (1992, 1993) studies. To calculate total factor productivity, econometric approach and growth accounting [arithmetic (AI) and Tornqvist-Theil Index (TTI)] are the two approaches which generally are being used to calculate total factor productivity, Antle and Capalbo (1988). Compared to arithmetic index, Tornqvist is more comprehensive and it determines time variation appropriately. 


\subsection{Estimation techniques}

As like Rosegrant et al. (1999), the Tornqvist-Theil approximation to the Divisia Index is used to generate the variable of total factor productivity (TFPC) through aggregation method of outputs and inputs. Because Tornqvist or Tornqvist-Theil price index is the weighted geometric average of the price relatives using arithmetic averages of the value shares in the two periods as weights. The index approach uses prices and quantities in two time-periods, $(t-1)$ and $(t)$, for each of $n$ goods which are indexed by $i$. TornqvistTheil Index constructs an aggregation method of output and input. In this study for the construction of output index, yield $\mathrm{kg} / \mathrm{ha}$ of cotton has been taken into account when it is separately multiplied with the respective prices of the crop to obtain total revenue of the crop for each year for both of the countries. Inputs index included human labor employed in the agriculture sector and fertilizer consumption (quantity of nitrogen, potash, and phosphate) multiplied with their prices. For the calculation of labor cost, machinery cost, and irrigation cost, relative quantities of the variable, respectively, multiplied with their prices.

\subsection{Tornqvist-Theil Index}

$$
\operatorname{LnTFPC}=1 / 2\left(R_{i \mathrm{t}}+R_{i \mathrm{t}-1}\right) \operatorname{Ln}\left(Y_{i \mathrm{t}} / Y_{i \mathrm{t}-1}\right)-1 / 2\left(S_{i \mathrm{t}}+S_{i \mathrm{t}-1}\right) \operatorname{Ln}\left(X_{i \mathrm{t}} / X_{i \mathrm{t}-1}\right),
$$

where $R_{i \mathrm{t}}$ is the share of output $I$ in the total revenue, $Y_{i \mathrm{t}}$ is output $i, S_{j \mathrm{t}}$ is the share of input $j$ in total input cost, and $X_{j \mathrm{t}}$ in input $j$, the total factor productivity will be measured for each year. For the calculation of total factor productivity, in this study, the growth formula has been used:

$$
\begin{aligned}
& \text { TFPC }=\text { output }- \text { input. } \\
& \text { TFPC }=Y_{i t} / X_{i t} .
\end{aligned}
$$

\subsection{Productivity-research relationship: model and estimation}

TFPC $=f($ ac, IRC, irtw, tract, elect, impsed, edu, fert, lf).

This section proves that an attempt to get the residual of $\mathrm{TFPC}_{i j}$ using Tornqvist-Theil index approach from the above-said procedure will make possible to test the hypothesis that increase in investment expenditure (increase in the number of available tractors, government expenditures on education, and research and development), improvement in infrastructure (lining of water courses, construction of dams, roads, and marketing facilities), and modernization of farm inputs (HYV seeds, and usage of chemical and pesticides besides fertilizers), increase the total factor productivity of the crops. For the analysis of this approach in this study, Savvides and Zachariadis's (2005), Shabbir (2018), Hulten and Isaksson (2007) general form of the model is being used:

$$
\operatorname{TFPC}_{\mathrm{t} i j}=\alpha+\alpha \mathrm{ac}_{\mathrm{t} i j}+\alpha \mathrm{irc}_{\mathrm{t} i j}+\alpha \mathrm{irtw}_{\mathrm{t} i j}+\alpha \operatorname{tract}_{\mathrm{t} i i}+\mathrm{elect}_{\mathrm{t} i j}+\alpha \mathrm{impsed}_{\mathrm{t} i j} \alpha \mathrm{edu}_{\mathrm{t} i j}+\alpha \mathrm{lf}_{\mathrm{t} i j}+\alpha \mathrm{fert}_{\mathrm{t} i j}+\varepsilon_{\mathrm{t} i} .
$$

\subsection{Independent variables in the model}

1. Area of the $\mathrm{crop}=\mathrm{Ac}$ (area of cotton)

2. Irrigation by canal water $=\operatorname{Irc}$

3. Irrigation by tube well water $=\mathrm{Irtw}$ 
4. Number of tractors available in country $=$ Tract

5. Distribution of $\mathrm{HYV}=$ impsed

6. Electricity consumption of agriculture sector $=$ elect

7. $\mathrm{R}=$ research expenditure on research and development besides education. million rupees $=\mathrm{Ed}$

8. Fertilizer consumption per $\mathrm{crop}=$ Fert

9. Labour force employed in agriculture sector $=\mathrm{Lf}$

10. $\varepsilon=$ error term.

(Ac) area of the crop (cotton), irc, and irtw as a measure of water availability for the agriculture sector. Education expenditure is the most important variable for the integration of growth process, Tufail and Ahmed (2015), Rosegrant and Evenson (1993), whereas some used number of years of schooling variable as a proxy for human capital, such as Benhabib and Spiegal (1994). An available number of tractors in a country are used in this research as the proxy of road infrastructure and improvement in marketing facilities, and electricity consumption in the agriculture sector $(\mathrm{GWH})$ has been used as an explanatory variable. Apart from this, on-farm input regressor is modern farm inputs: HYV seeds, fertilizer consumption per crop, and labor force employed in the agriculture sector are the important variables and major determinants of the total factor productivity of the crop (Chaudhary 2012). All of the above-mentioned variables have been taken from, Economic Survey of Pakistan, Agriculture Statistics of Pakistan, Union Budget India, Agriculture Statistics at a Glance India, Indian Reserve Bank, ILO (international labor statistics) at a glance. The number of tractors available in economy and expenditure on education data is taken from the World Bank and from index mundi.com, and fertilizer consumption data are taken from FAO statistics. In this study, time-series data from 1954 to 2015 have been used separate regression for each country (Pakistan and India), and have been regressed. Like Rosegrant and Evenson (1993) did in his study to compare the productivity of wheat of India and Pakistan due to the arrival of agro-technology in the agriculture sector.

\subsection{Estimation of the model}

Pesaran and Shin $(1999,2001)$ originally developed the ARDL: an autoregressive distributive lag model for time-series analysis. The model has numerous advantages, such as it has the capability to check the stationery of the variables on level (0) and the first difference using an accurate level of significance. For comparative analysis and to check the effect of technology on the dependent variable, the ARDL model is an appropriate technique, and it is the most recent model, because it generates long-run and short-run coefficient simultaneously and follows the OLS procedure for cointegration among the variables. Moreover, it is a flexible model in terms of variables integration order, and the model does not ask for pre-testing of the variables: 


$$
\begin{aligned}
& \Delta \mathrm{TFPC}_{i, j}= \beta_{0}+\sum_{i, j=t}^{t} \emptyset \Delta \mathrm{TFPC}_{t-i, j}+\sum_{i, j=t}^{t} \theta \mathrm{ac}_{t-i, j}+\sum_{i, j=t}^{t} \delta \mathrm{ic}_{i, j-t}+\sum_{i, j-t}^{t} \gamma \mathrm{it}_{i, j-t} \\
&+\sum_{i, j-t}^{t} \partial t_{i, j-t}+\sum_{i, j-t}^{t} \propto p_{i, j-t}+\sum_{i, j-t}^{t} \forall \mathrm{is}_{i, j-t}+\sum_{i, j-t}^{t} \omega e_{i, j-t} \\
&+\sum_{i, j-t}^{t} \tau f_{i, j-t}++\sum_{i, j-t}^{n} \pi l_{i, j-t}+\varepsilon_{t} \\
& a_{\mathrm{Ct}-\mathrm{i}, j}+\alpha_{2} \operatorname{irc}_{t-i, j}+\alpha_{3} \operatorname{irtw}_{t-i, j}+\alpha_{4} \operatorname{tract}_{t-i, j}+\alpha_{5} \operatorname{elect}_{t-i, j} \\
&+\alpha_{6} \operatorname{impsed}_{t-i, j}+\alpha_{7} \operatorname{edu}_{t-i, j}+\alpha_{8} \mathrm{fert}_{t-i, j}+\alpha_{9} \mathrm{lf}_{t-i, j}+\varepsilon_{t} .
\end{aligned}
$$

\subsection{Unit root test}

$\beta_{0}$ is the drift component, whereas $\alpha, \pi, \tau, \varnothing, \theta, \delta, \gamma, \partial, \forall, \omega, \tau$, and $\varepsilon$ are short-run parameters, and $\alpha_{1}, \alpha_{2}, \alpha_{3}, \alpha_{4}, \alpha_{5}, \alpha_{6}, \alpha_{7}, \alpha_{8}$, and $\alpha_{9}$ are long-run parameters. In this study unit, root test serves as the very first method to check the long-run cointegration relationship among the variables, TFPC and given explanatory regressor. Unit root test is the best measure to test the stationarity, because it provides multiple options for the estimation. There is a wide range of unit root test, but in this study, ADF (Augmented Dickey and Fuller 1979) is being used due to its being extensive in nature, and the test is based on the first-order autoregressive process (Box and Jenkins 1970):

$$
\begin{aligned}
& \text { TFPc }_{\mathrm{ti}}=\alpha_{1} y_{\mathrm{ti}-1}+\varepsilon_{\mathrm{ti}} \\
& \mathrm{H}_{0}: \alpha_{1}=\alpha_{2}=\alpha_{3}=\alpha_{4}=\alpha_{5}=\alpha_{6}=\alpha_{7}=\alpha_{8}=\alpha_{9}=1 \text { (not stationary) } \\
& \mathrm{H}_{1}: \alpha_{1}=\alpha_{2}=\alpha_{3}=\alpha_{4}=\alpha_{5}=\alpha_{6}=\alpha_{7}=\alpha_{8}=\alpha_{9} \# 1 \text { (stationary). }
\end{aligned}
$$

As per the definition of unit root ADF if the process contains a unit root:high probability value $\rho$, then, there is no long-run cointegration relationship exist between the dependent and independent variables; however, if there is low $\rho$ value, then it indicates there is long-run cointegration relationship exist among the variables of the model and variable called stationary in the long run. ARDL bound test uses $f$-statistic's upper and lower bound values to determine the long-run cointegration relationship.

If $F$-statistics $>10 \%, 5 \%, 1 \%$ (long-run co integration relationship exist).

If $F$-statistics $<10 \%, 5 \%, 1 \%$ (no long-run co integration relationship exist).

If $F$-statistics lies between the upper and lower bound of the significance limit, then result is in conclusive.

ARDL uses Akaike's information criteria (AIC) and Schwarz Bayesian criteria (SBC) to check the log length to estimate the long-run cointegration relationship. Once through ARDL results besides AIC and SBC criteria the existence of long-run cointegration relationship gets prove. After this, we can run the regression of long-run parameters, with addition to the short-run vector error correction model, for short-run analysis. VECM has an advantage that it explores the value of the speed of adjustment among the variables from the short run to long run (Tufail and Ahmed 2015). Nkoro and Uko (2016) explained that ECt explains the speed of adjustment from disequilibrium to equilibrium 
Table 1 Unit root test

\begin{tabular}{|c|c|c|c|c|c|c|}
\hline & \multicolumn{3}{|l|}{ Pakistan } & \multicolumn{3}{|l|}{ India } \\
\hline & At level & 1 st diff. & Decision & At level & 1st diff. & Decision \\
\hline TFPCC & $-8.56(0.000)^{* * *}$ & $-5.8(0.000)^{* * *}$ & $\mathrm{I}(0)$ & $-4.88(0.00)^{* * *}$ & $-4.92(0.00)^{* * *}$ & $\mathrm{I}(0)$ \\
\hline $\mathrm{ac}$ & $-0.32(0.98)$ & $-1.12(0.000)^{* * *}$ & $\mid(\mid)$ & $0.005(0.99)$ & $-7.68(0.000)^{* * *}$ & $I(I)$ \\
\hline IrC & $-3.15(0.108)$ & $-9.74(0.000)^{* * *}$ & $\mid(\mid)$ & $-0.86(0.953)$ & $-5.77(0.0001)$ & $I(I)$ \\
\hline Irtw & $-2.2(0.448)$ & $-3.35\left(0.068^{*}\right)$ & $\mid(\mid)$ & $-2.89(0.17)$ & $-7.76(0.00)^{* * *}$ & $I(I)$ \\
\hline Tract & $-4.8(0.001)$ & $-1.03(0.99)$ & $\mathrm{I}(0)$ & $-4.98(0.00)^{* * *}$ & $-1.52(0.118)$ & $\mathrm{I}(0)$ \\
\hline impsed & $-2.4(0.327)$ & $-6.19(0.00)^{* * *}$ & $\mid(\mid)$ & $-1.7(0.737)$ & $-9.93(0.000)^{* * *}$ & $I(I)$ \\
\hline Fert & $-2.5(0.286)$ & $-8.19(0.000)^{* * *}$ & $I(I)$ & $-7.83(0.000)^{* * *}$ & $-6.63(0.000)^{* * *}$ & $\mathrm{I}(0)$ \\
\hline Edu & $-0.49(0.99)$ & $-4.56(0.000)^{* * *}$ & $\mid(\mid)$ & $-3.03(0.13)$ & $-5.35(0.000)^{* * *}$ & $\mid(I)$ \\
\hline Elect & $-3.39(0.06)^{*}$ & $-8.3(0.000)^{* * *}$ & $\mathrm{I}(0)$ & $-3.93(0.016)^{*}$ & $-8.22(0.000)^{* * *}$ & $\mathrm{I}(0)$ \\
\hline If & $-3.9(0.018)^{*}$ & $-6.87(0.000)^{* * *}$ & $\mathrm{I}(0)$ & $0.71(0.99)$ & $-2.85(0.056)^{*}$ & I(I) \\
\hline
\end{tabular}

Probability values are in parenthesis; they are significant at ${ }^{*} 10 \%,{ }^{* *} 5 \%,{ }^{* * *} 1 \%$

ECt value should be between -1 and 0 . However, Narayan and Smith (2006) says that it can be between -1 and -2 .

\section{Results and discussion}

\subsection{Unit root test}

For time-series analysis, it is imperative to check the stationarity, because most of the time-series data exhibit non-stationary trend and leads to the spurious regression results. Therefore, to deal with this problem, augmented Dickey and Fuller's (1979) test is the best measure to avoid such misleading outcomes. The test follows the given below null hypothesis: that the variable under consideration has unit root and it is not stationary, whereas alternative hypothesis rejects the above-said claim and accepts that variable in interest is stationary. The rejection and acceptance of the hypothesis depend on the computed values of ADF values on its level of significance at 1 and 5 percent in Table 1.

Table 1 shows the unit root test results for both Pakistan and India. TFPCc is stationary at a level for both countries; AC, Irc, and irtw are stationary at first difference for both Pakistan and India. Tractor is stationary at a level in two of the countries, whereas HYV seeds, fertilizer consumption kg per hectare, are stationary at their first difference, expenditure on education, electricity consumption in the agriculture sector, besides labor force are stationary at first order, in Pakistan and India. The above-given results of ADF test depict the picture that there is no correlation among the variable and all of them are stationary, and $I \rho I<1$.

\subsection{Total productivity of cotton comparative analysis of Pakistan and India}

The bound test results for cotton total factor productivity are in Table 2; in this table Pakistan and India, both $f$-statistics are given which shows that both of the countries $f$-statistics are greater than to their all significant critical values. Therefore, it can be concluded as Fcu > Fcr value; thereby, there exits long-run cointegration relationship among the terms of the variable of both countries. However, the relationship is stronger in the case of India than to Pakistan due to greater $f$-statistics value, as shown in Table 2. 
Table 2 Cotton total factor productivity (ARDL bound test)

\begin{tabular}{|c|c|c|c|c|}
\hline \multirow[t]{2}{*}{ Test statistic } & \multicolumn{2}{|l|}{ Pakistan } & \multicolumn{2}{|l|}{ India } \\
\hline & Value & $k$ & Value & $K$ \\
\hline F-statistic & 6.804606 & 9 & 15.44055 & 9 \\
\hline \multirow[t]{2}{*}{ Significance (\%) } & \multicolumn{2}{|c|}{ Critical value bounds } & \multicolumn{2}{|c|}{ Critical value bounds } \\
\hline & 10 bound & 11 bound & 10 bound & I1 bound \\
\hline 10 & 1.88 & 2.99 & 1.88 & 2.99 \\
\hline 5 & 2.14 & 3.3 & 2.14 & 3.3 \\
\hline 2.50 & 2.37 & 3.6 & 2.37 & 3.6 \\
\hline 1 & 2.65 & 3.97 & 2.65 & 3.97 \\
\hline
\end{tabular}

Table 3 Total factor productivity of cotton long-run cointegration

\begin{tabular}{|c|c|c|c|c|c|c|}
\hline \multirow[t]{2}{*}{ Variable } & \multicolumn{3}{|l|}{ Pakistan } & \multicolumn{3}{|l|}{ India } \\
\hline & Coefficient & Std. error & $t$-Statistic & Coefficient & Std. error & $t$-Statistic \\
\hline$A C$ & $0.00(0.01)^{*}$ & 0 & 2.96 & $-0.05(0.02)^{*}$ & 0.02 & -2.47 \\
\hline IMPSED & $0.01(0.31)$ & 0.01 & 1.03 & $0.004(0.01)^{*}$ & 0 & 2.89 \\
\hline FERT & $0.0036(0.03)^{*}$ & 0 & -2.22 & $-0.0005(0.00)^{* *}$ & 0 & -4.41 \\
\hline ELEC & $-0.08(0.08)^{*}$ & 0.04 & -1.83 & $-0.004(0.00)^{* *}$ & 0 & -3.21 \\
\hline EDU & $0.01(0.26)$ & 0.01 & 1.13 & $-0.001(0.06)^{*}$ & 0 & -1.96 \\
\hline IRC & $0.26(0.00)^{* *}$ & 0.07 & 3.85 & $0.01(0.87)$ & 0.04 & 0.17 \\
\hline IRTW & $-0.29(0.01)^{*}$ & 0.11 & -2.59 & $0.04(0.10)$ & 0.02 & 1.69 \\
\hline LF & $-0.01(0.00)^{* *}$ & 0 & -3.25 & $1.01(0.22)$ & 0.81 & 1.26 \\
\hline TRACT & $0.00(0.01)^{*}$ & & 2.86 & $0.00(0.00)^{* *}$ & 0 & 3.43 \\
\hline C & $-4.03(0.00)^{* *}$ & 1.07 & -3.79 & $-4.77(0.22)$ & 3.85 & -1.24 \\
\hline CointEq(-1) & $-0.98(0.00)^{* *}$ & 0.17 & -5.81 & $-0.84(0.00)^{* *}$ & 0.13 & -8.79 \\
\hline
\end{tabular}

Probability value in parenthesis shows level of significance $* 10 \%, * * 5 \%$, and ${ }^{* * *} 1 \%$. Sources: TFP is calculated by author using self-survey data for both countries. Besides economic survey of Pakistan, agriculture statistics of Pakistan, Indian agriculture statistics at a glance, Indian bureau of labor statistics, FAO data of fertilizer consumption per country, and no of tractors data are taken from World Bank

Table 3, presents the results of total factor productivity of cotton long-run cointegration comparative analysis of Pakistan and India over the time period of 19542017. Area of the crop is significant and has a positive relationship with TFPCc in Pakistan's case. Contrast to this negative but significant in terms of Indian cotton area productivity, HYV seeds are insignificant in terms of Pakistan besides being negative, but positive and highly significant in India. Fertilizer consumption kg per hectare, electricity consumption in the agriculture sector, irrigation by tube wells, agriculture labor force, and education expenditure have a negative relationship with total factor productivity of cotton in case of India, fertilizer consumption, education expenditure, and electricity consumption are highly significant though negative. Irrigation by tube wells and labor force employed in the agriculture sector are insignificant in terms of India. However, irrigation by canal water and number of tractors available in the country is positive, but tractor has a highly significant impact on total factor productivity of the crop. Contrast to India, fertilizer, irrigation by canal water, expenditure on education, and tractor results are showing a positive relationship with the 
productivity of the crop. However, fertilizer consumption, irrigation by canal water, and tractor as a proxy of improvement in infrastructure are significant. Electricity consumption, irrigation by tube wells, and labor force employed in the agriculture sector have a negative but significant relationship with TFPCc in case of Pakistan.

The $t$-statistics value and probability value of Pakistan are better than India, the reason of this trend is that in India, cotton is being cultivated on small holdings compare to Pakistan, where still big farmers have a comparative advantage than to India. Ramasundaram et al. (2001) also acknowledged that the major hurdle in the low factor productivity of the crop is predominantly small holdings. Canal water expansion (IC) (0.26) is positive and significant at 5 percent in Pakistan's case, and has a positive impact on total factor productivity of the crop (TFPC), canal water accelerated growth of the plant more vigorously than to tube well water. However, the coefficient of tube well water is negative $(-0.29)$ in Pakistan and positive in India, but the probability of the variable is significant in Pakistan, but insignificant in the case of Bangladesh. The prime reason of this negative trend in Pakistan is that mainland of cotton are in middle, upper, and southern Punjab, and due to the intensive tube well irrigation water, aqua fires of these areas have been degraded besides being contaminated by over and inefficient fertilization. Due to this reason instead of increasing productivity, tube well water irrigation causing to decrease total factor productivity of the cotton in the country. Both variable of water irc (0.01) and irtw (0.04) are positive in but insignificant. Numbers of tractors which are available in both countries are highly significant in Pakistan (0.01) and India (0.00), because the variable of the tractor is also being used on this research as a proxy variable of the total increase in road surface area and infrastructural development. Government expenditure on education (0.01) is positive but insignificant in Pakistan, whereas negative and significant in India.

Though with the passage of time, government expenditure has increased in India and Pakistan as well, yet allocation of the resources are not up to the requirement of the countries. Especially in India where the population is divided into classes and most of the cotton grower's mainland are in the deprived region. Resultantly, instead of to increasing total factor productivity of the crop, it is decreasing. The coefficient of high yield variety seeds is also showing a positive relationship with total factor productivity of cotton in both countries. Results explore that output of the crop has been increased rapidly since the advent of HYV seeds in Pakistan (0.01) and India (0.004), ${ }^{2}$ and since 1992 in Pakistan and since 2002 in India when the government of both countries introduced BT cotton production in their countries. BT assumes a lot of importance in this situation; the variety helps farmers in terms of pest-resistant American boll warm and raises productivity in Pakistan and India. Since the adoption of variety, there is a steep increase in the area of cotton in two of the countries. In addition, these have transformed from net importers to exporter Sadashivappa and Qaim (2009), Fatima et al. (2016), Dagar and Yadav (2017). Fertilizer consumption has a negative value in terms of India $(-0.0005)$, which means that every 1-ton increase in fertilizer consumption leads to decrease total factor productivity of cotton over the time period; the reason of this decline is those still farmers in India are not enough

\footnotetext{
${ }^{2}$ Bacillus thuringiensis.
} 
Table 4 Short-run vector error correction model

\begin{tabular}{|c|c|c|c|c|}
\hline \multicolumn{5}{|c|}{ Short-run error correction model } \\
\hline \multirow[t]{2}{*}{ Variable } & \multicolumn{2}{|l|}{ Pakistan } & \multicolumn{2}{|l|}{ India } \\
\hline & Coefficient & $t$-Statistic & Coefficient & t-Statistic \\
\hline $\mathrm{D}(\operatorname{TFPCC}(-1))$ & $-0.24(0.04)$ & -2.17 & & \\
\hline$D(A C)$ & $0.00(0.00)$ & 3.78 & $-0.01(0.63)$ & -0.49 \\
\hline D(IMPSED) & $0.01(0.32)$ & 1.01 & $0.01(0.00)$ & 6.39 \\
\hline $\mathrm{D}(\mathrm{FERT})$ & $0.00(0.07)$ & 1.88 & $0.00(0.55)$ & -0.6 \\
\hline $\mathrm{D}(\mathrm{FERT}(-1))$ & $0.00(0.07)$ & 1.84 & $0.00(0.00)$ & 4.58 \\
\hline $\mathrm{D}(\mathrm{FERT}(-2))$ & & & $0.00(0.00)$ & 5.31 \\
\hline $\mathrm{D}(\mathrm{ELEC})$ & $-0.08(0.07)$ & -1.86 & $0.00(0.00)$ & 3.35 \\
\hline $\mathrm{D}(\mathrm{ELECT}(-1))$ & & & $0.00(0.07)$ & 1.87 \\
\hline $\mathrm{D}(\mathrm{ELECT}(-2))$ & & & $0.00(0.34)$ & 0.97 \\
\hline $\mathrm{D}(\mathrm{ELECT}(-3))$ & & & $0.00(0.00)$ & 5.1 \\
\hline $\mathrm{D}(\mathrm{EDU})$ & $0.01(0.44)$ & 0.78 & $0.00(0.06)$ & -1.91 \\
\hline $\mathrm{D}(\mathrm{EDU}(-1))$ & $0.01(0.75)$ & 0.32 & & \\
\hline $\mathrm{D}(\mathrm{EDU}(-2))$ & $-0.08(0.00)$ & -3.05 & & \\
\hline $\mathrm{D}(\mathrm{EDU}(-3))$ & $0.09(0.00)$ & 4.27 & & \\
\hline $\mathrm{D}(\mathrm{IRC})$ & $0.25(0.00)$ & 4.88 & $0.01(0.87)$ & 0.17 \\
\hline D(IRTW) & $-0.28(0.00)$ & -3.01 & $0.05(0.09)$ & 1.75 \\
\hline $\mathrm{D}(\mathrm{LF})$ & $0.00(0.87)$ & 0.17 & $1.20(0.22)$ & 1.24 \\
\hline $\mathrm{D}(\mathrm{TRACT})$ & $0.00(0.00)$ & 3.06 & $0.00(0.00)$ & 3.11 \\
\hline
\end{tabular}

efficient to use fertilizer. Thereby, inefficient methods of fertilizer consumption are responsible to engender new disease. ${ }^{3}$ Therefore, it is negative despite being significant, and results are similar to Raza and Siddiqui (2014), Shabbir and Rehman (2015), Kranthi (2016), who also found a negative relationship between productivity and fertilizer consumption. Electricity (elect) is also significant and negative in the context of Pakistan and India, both due to weak infrastructure and higher tariff rate on agriculture per unit rate since 1990. Labor for employed in agriculture sector relationship with the productivity of crop is negative as per the results of the study, though significant in terms of Pakistan. However, the variable of labor force showing the positive relationship in the case of India, but it is insignificant. Amjad and Awais (2015) found that for the last 35 years, total factor productivity of the agriculture sector is decreasing due to the inefficient and unskilled agriculture labor force. The speed of adjustment from short-run disequilibrium to long-run equilibrium in Pakistan -0.98 is -0.98 , whereas in India, it is -0.84 , in a year which shows rapid and smooth adjustment from short run to long run.

Table 4 explores the results of vector error correction model for the short-run analysis of Pakistan and Indian cotton total factor productivity over the time period (1954-2017). The coefficients of the vector error correction model based on maximum three lag length and Error Correction Term. The result shows that VECM value is correctly negative and significant, so there is also a short-run relationship found in the model of the study. The model has been selected on the basis of AIC, LR, SC, and HQ criteria.

\footnotetext{
${ }^{3}$ Especially, it contaminates groundwater resources, which became hazardous for the crop productivity.
} 
Table 5 Goodness of fit

\begin{tabular}{lcr}
\hline & Pakistan & India \\
\hline$R$-squared & 0.858 & 0.863 \\
Adjusted R-squared & 0.640 & 0.790 \\
S.E. of regression & 0.200 & 0.129 \\
Sum squared resid & 0.884 & 0.601 \\
Log-likelihood & 37.852 & 47.501 \\
F-statistic & 3.925 & 11.900 \\
Prob(F-statistic) & 0.001 & 0.000 \\
Mean dependent var & 0.011 & 0.003 \\
S.D. dependent var & 0.334 & 0.282 \\
Akaike info criterion & -0.100 & -0.982 \\
Schwarz criterion & -0.154 & -0.259 \\
Hannan-Quinn criteria & -0.387 & -0.702 \\
Durbin-Watson stat & 2.285 & 2.345 \\
\hline
\end{tabular}

Table 6 Test to check auto correlation and heteroskedasticity

\begin{tabular}{lll}
\hline Pakistan & & India \\
\hline Cotton & & \\
Serial correlation & 0.947957 & 1.5775984 \\
& $0.4022^{*}$ & $0.2303^{*}$ \\
Heteroskedasticity & 0.672612 & 0.540027 \\
Ramsey test & $0.8536^{*}$ & $0.9468^{*}$ \\
& 0.009833 & 0.03369 \\
& $0.9218^{*}$ & $0.8560^{*}$ \\
\hline
\end{tabular}

* Probability values

Table 5 shows the overall summary of the fitted Model, $P$ value of Pakistan (0.001) and India (0.000) discloses that $f$-statistics results are reliable, and there exists long-run cointegration relationship among the variables. Furthermore, that overall model is significant, because the value of adjusted $R$-square is 0.64 (Pakistan) and 0.79 (India) which shows that there is enough variation in the endogenous variable of the countries which is explained by exogenous variables, which means that the overall model is good fitted.

Table 6 shows that there is no serial, heteroscedasticity, and autocorrelation in the estimated model for both countries. The model of this study is the best fit and does not suffer major issues.

\section{Conclusions}

After analyzing the non-farm and farms inputs impact on the productivity of cotton in terms of comparative analysis of Pakistan and India. Results of the long-run cointegration ARDL model explore that farm input has a positive relationship with the productivity of crop in terms of Pakistan. The area under cotton cultivation fertilizer consumption $\mathrm{kg} / \mathrm{ha}$, irrigation by canal water, and number of tractors are not only positive but significant also, whereas HYV seeds and expenditure on education are only positive and insignificant. This shows that the rise in productivity is due to the modern farm input usage. However, electricity consumption, irrigation by tube wells, 
and labor force showed a negative relationship with the productivity of the crop. Contrast to Pakistan, results of the Indian ARDL model regression depict that area of cotton, fertilizer consumption $\mathrm{kg} / \mathrm{ha}$, electricity consumption in the agriculture sector, and the variable of education have significant negative relationship with the productivity of crop, as per the results of long-run cointegration model. However, irrigation by canal water, tube well water, number of tractors available in the economy, and labor force employed in the agriculture sector are positive but insignificant, except tractor which is significant. Notwithstanding, HYV seeds are highly significant and positive in terms of India's-statistics. Apart from this value of the bound test, cointegration and R statistics show that model is correctly specified and there is long-run relationship exists among the variable; moreover, agriculture sectors of the countries are not neutral to scale. The results of the ARDL disclosed that it is an inefficient allocation of resources is the real reason of stagnant growth and cause of decrease in the area of cotton in Pakistan. Thereby, only improvement in human capital formation sustainable development can achieve. Contrast to Pakistan, in India, productivity is not much higher than to Pakistan, and both of the countries more or less are similar to each other, although, area, high yield variety seeds, and tractors are contributing in Indian cotton productivity substantially.

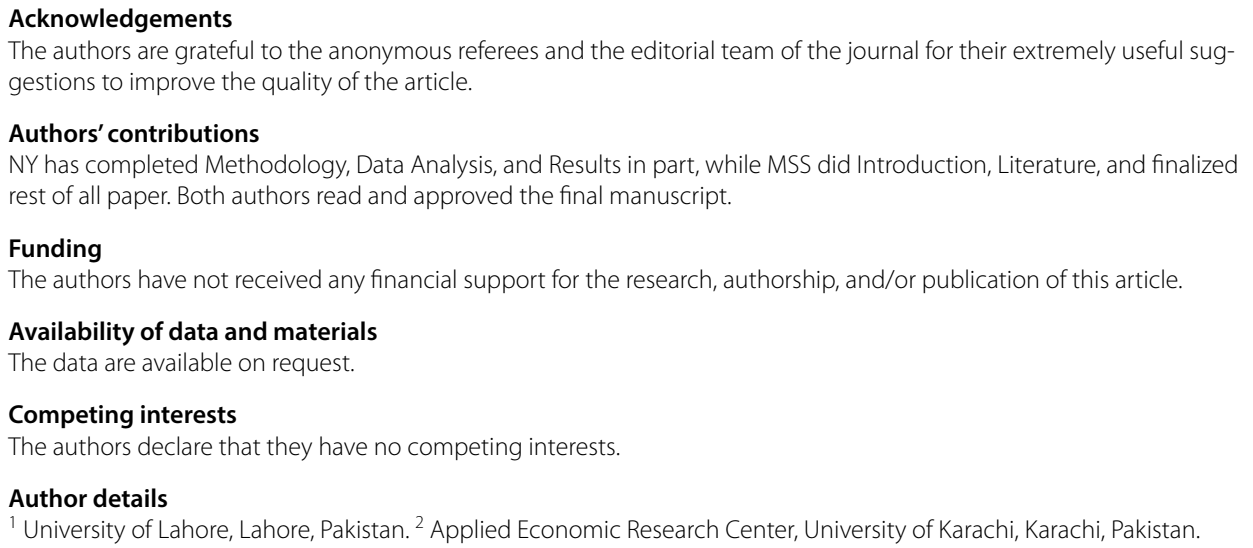

\section{Appendix}

Data sources

AGRICULTURE-Statistical Year Book India 2017 | Ministry of agriculture. https:// mospi.nic.in/statistical-yearbook-india/2017/177.

Agriculture Statistics. Pakistan Bureau of Statistics. www.pbs.gov.pk/agri-stat-tables.

Annual Report | Ministry of Labour and Employment. https://labour.gov.in/annua 1-reports.

Fertilizer Use by Crop-FAO. www.fao.org/tempref/docrep/fao/009/a0257e/a0257 e06.pdf.

Labor Bureau Statistics-Outlook India. https://www.outlookindia.com/website/ story/india-is.labour.statistics/3105.

Fertilizer Use by Crop-FAO. www.fao.org/tempref/docrep/fao/009/a0257e/a0257 e06.pdf.

Government of India (2017), Agricultural Statistics at a Glance. 
Handbook of Statistics on Indian Economy.

Annual Report | Ministry of Labour \& Employment. https://labour.gov.in/annua

l-reports.

https://www.outlookindia.com/website/story/india-is.labour.statistics/3105.

Indian Agriculture Statistics.

Reserve Bank of India-Handbook of Statistics on Indian.

Central Electricity Authority Govt of India.

USDA World cotton outlook 2017-2018.

USDA world cotton outlook 2019.

World Bank.

Received: 27 April 2019 Revised: 5 July 2019 Accepted: 25 July 2019

Published online: 20 August 2019

\section{References}

Ali S (2004) Productivity growth in Pakistan's agriculture, 1960-1996. Pak Dev Rev 43(4):493-513

Ali M, Byerlee D (2000) Productivity growth and resource degradation in Pakistan's Punjab: a decomposition analysis. World Bank Policy Research, working Paper No. 2480

Amjad R, Awais N (2015) Pakistan's productivity performance and TFP trends, 1980-2015: cause for real concern. Lahore J Econ 21:33-63

Antle J, Capalbo S (1988) Agricultural productivity: measurement and explanation. Johns Hopkins University Press, Washington, D.C

Ashraf S, Sangi AH, Hassen ZY, Mohammed L (2018) Future of cotton sector in Pakistan: a 2025 outlook. Pak J Agric Res 31(2):145-150

Benhabib J, Spiegal MM (1994) The role of human capital in economic development evidences from aggregate crosscountry data. 34(2):143-173. https://doi.org/10.1016/0304-3932(94)90047-7

Box GEP, Jenkins GM (1970) Time series analysis forecasting and control. San Francisco hold on day. Wiley, New York

Chang H, Zepeda L (2001) Agricultural productivity for sustainable food security in Asia and the pacific: the role of investment. In: Zepeda L (ed) Agricultural investment and productivity in developing countries. FAO Economic and Social Development Paper 148. University of Wisconsin-Madison, USA

Chaudhary S (2012) Trends in total factor productivity in Indian agriculture: state-level evidence using non-parametric sequential Malmquist index. Working Paper No. 215 Centre for Development Economics Department of Economics, Delhi School of Economics

Christensen LR (1975) Concept and measurement of agriculture productivity. Am J Agric Econ 55(5):910-915

Coelli TJ, Rao DS (2003) Total factor productivity growth in agriculture: a Malmqvist index analysis of 93 countries, 1980-2000. In: Written for presentation as a plenary paper at the 2003 International Association of Agricultural Economics IAAE Conference, Durban

Coen RM, Eisner R (1987) Investment. In: Eatwell J, Milgate M, Newman P (eds) The new Palgrave dictionary of economics, vol 2. Stockson Press, New York

Cornejo JF, Shumway CR (1997) Research and productivity in Mexican agriculture. Am J Agric Econ 79(3):738-753

Dagar JC, Yadav RK (2017) Climate resilient approach for enhancing productivity of saline agriculture. J Soil Salin Water Qual 9(1):9-29

Dean ER, Harper MJ, Hulten CR (1998) New developments in productivity analysis. In: Conference paper held in Silver Spring marry land on 21-22 March 1998

Denison EF (1967) Sources of post-war growth in nine western countries. Am Rev. https://doi.org/10.17582/journ al.pjar/2018/31.2.145.150

Dickey DA, Fuller WA (1979) Distribution of the estimator for auto regressive time series with unit root. J Am Stat Assoc 74:427-431

Eisner R (1985) The total incomes system of accounts. Survey of Current Business, 56 January: 24-48

Fatima H, Khan MA, Zaid-Ullah M, Jabbar A, Saddozai KN (2016) Technical efficiency of cotton production in Pakistan: a comparative study on non BT and BT-cotton farms. https://doi.org/10.17582/journal.sja/2016/32.4.267.274

Fernald JG, Ramnath S (2004) The acceleration in us total factor productivity after 1995: role of information technology. Econ Perspect Fed Reserve Bank Chicago 28(1):52-64

Hulten CR, Isaksson A (2007) Why development levels differ: the sources of differential economic growth in a panel economic growth in a panel of low and high income countries. National Bureau of Economic Research, 2007

Jin S, Huang J, Hu R, Rozelk S (2002) The creation of technology and total factor productivity in china's agriculture. Am J Agric Econ 8(4):916-939

Kendrick JW (1973) Postwar productivity trends in the United States, 1948-69. National Bureau of Economic Research, New York

Khan MH (1997) Agricultural 'crisis' in Pakistan: some explanations and policy options. Pak Dev Rev 6(4):419-459

Kranthi KR (2016) Cotton statistics and news. Indian society for cotton improvement, Mumbai, pp 1-6 
Mukherjee AN, Kuroda Y (2003) Productivity growth in Indian agriculture: is there evidence of convergence across states? J Agric Econ 29:43-53

Narayan PK, Smith R (2006) What determines migration flow from income to high income countries An empirical investigation of Fiji-US migration 1972-2001. Contemp Econ Policy 24(2):332-342. https://doi.org/10.1093/cep/byj019

Nokora E, Uko AK (2016) Autoregressive distributed lag (ARDL) cointegeration technique: application and interpretation. J Stat Econom Methods 5(4):63-91

Pesaran MH, Shin Y (1999) An autoregressive distributed lag modelling approach to co integration analysis. In: Strom S, Holly A, Diamond P (eds) Centennial volume of Ragnar Frisch. Cambridge University Press, Cambridge

Ramasundaram P, Hemchandra, Gajbhiye (2001) Constraints to cotton production in India. Central Institute for Cotton Research, Nagpur. www.cicr.org.in

Raza J, Siddiqui W (2014) Determinants of agriculture output in Pakistan a Johnson cointegration approach. Acad Res Int 5(4):30

Rehman A, Jingdong L, Chandio AA, Hussain I, Wagan SA, Memon QUA (2016) Economic perspectives of cotton crop in Pakistan: a time series analysis (1970-2015) (Part 1). J Saudi Soc Agric Sci 18(1):49-54

Rosegrant MW, Evenson RE (1992) Agriculture productivity and sources of growth in south Asia. Am J Agric Econ 74(3):757-761

Rosegrant MW, Evenson RE (1993) Agricultural productivity growth in Pakistan and India: a comparative analysis. Pak Dev Rev 32(4):433-451

Rosegrant MW, Leach N, Gerpacio RV (1999) Alternative futures for world cereal and meat consumption. Proc Nutr Soc 58(2):219-234

Sabir M, Ahmad QM (2003) Macro-economic reforms and total factor productivity growth in Pakistan: an empirical analysis. In: Conference paper No. 55 presented at the 56th International Atlantic Economic Conference, Quebec City, Canada

Sadashivappa P, Qaim M (2009) Bt cotton in India, development benefits and the role of government seed prices interventions. 12(2):172-183. http://www.agbioforum.org

Saleem H, Shahzad M, Khan MB, Khilji BA (2019) Innovation, total factor productivity and economic growth in Pakistan: a policy perspective. J Econ Struct 8(1):7

Sarel M, Robinson DJ (1997) Growth and productivity in ASEAN countries. International Monetary Fund IMF, Working Paper No. 97/97. IMF, Washington, D.C

Savvides A, Zachariadis M (2005) International technology diffusion and the growth of TFP in the manufacturing sector of developing economies. Rev Dev Econ 9(4):482-501

Shabbir M (2015) Innovation and competitiveness lead to industrial trade. Available at SSRN 2659847

Shabbir MS (2016) The impact of financial development on economic growth of Pakistan economy. Am Based Res J 5(3):35-43

Shabbir MS (2018) The impact of foreign portfolio investment on stock market of Pakistan. Int J Ethics Syst 6(2):16-26

Shabbir MS, Rehman AK (2015) The impact of financial crises and economic growth of East Asian Countries. J Internet Bank Commer 19(1):95-107

Shuli F, Jarwar AH, Wang X, Wang L, Ma Q (2018) Overview of the cotton in Pakistan and its future prospects. Pak J Agric Res 31(4):396-407

Solow RM (1957) Technical change and the aggregate production function. Rev Econ Stat 39(3):312-320

Tufail M, Ahmed AM (2015) Measuring total factor productivity and finding the determinants of total factor productivity at sectorial level: a case study of Pakistan. Ind Eng Lett 5(6):38-53

Wizarat S (1981) Technological change in Pakistan's agriculture: 1953-54 to 1978-79. Pak Dev Rev 20(4):427-445

\section{Publisher's Note}

Springer Nature remains neutral with regard to jurisdictional claims in published maps and institutional affiliations.

\section{Submit your manuscript to a SpringerOpen ${ }^{\circ}$ journal and benefit from:}

- Convenient online submission

- Rigorous peer review

- Open access: articles freely available online

- High visibility within the field

- Retaining the copyright to your article

Submit your next manuscript at $\boldsymbol{\nabla}$ springeropen.com 